$10-28-2019$

\title{
Discarding Old Prejudices: Judicial Precedent and Aboriginal Title
}

Kent McNeil

Osgoode Hall Law School of York University, kmcneil@osgoode.yorku.ca

Follow this and additional works at: https://digitalcommons.osgoode.yorku.ca/conference_papers

Part of the Law Commons

\section{Recommended Citation}

McNeil, Kent, "Discarding Old Prejudices: Judicial Precedent and Aboriginal Title" (2019). Conference Papers. 9.

https://digitalcommons.osgoode.yorku.ca/conference_papers/9

This Conference Proceeding is brought to you for free and open access by the Research Papers, Working Papers, Conference Papers at Osgoode Digital Commons. It has been accepted for inclusion in Conference Papers by an authorized administrator of Osgoode Digital Commons. 
Kent McNeil, "Discarding Old Prejudices: Judicial Precedent and Aboriginal Title," Law Foundation of Saskatchewan Lecture, U. of S. College of Law, October 28, 2019, based on the author's recent book, Flawed Precedent: The St. Catherine's Case and Aboriginal Title (Vancouver: UBC Press, 2019)

This talk on judicial precedent and Aboriginal title combines legal history and current law. The legal history is important because it informs the current law. It also reveals the racism in Canadian law that retarded the development of the concept of Aboriginal title until the 1970s.

My discussion of the early case law focuses on St. Catherine's Milling and Lumber Co. v. The Queen ${ }^{1}$ decided by the Privy Council in 1888. It was the leading judicial precedent on the source and content of Aboriginal title right up to the Supreme Court of Canada's 1973 decision in Calder v. Attorney General of British Columbia. ${ }^{2}$ The question in St. Catherine's was this: Did the Crown in right of Ontario or the Crown in right of Canada benefit from the surrender by the Saulteaux people of the Anishinaabe Nation of their Aboriginal title by Treaty 3 in 1873 ?

Treaty 3 covers lands around the Lake of the Woods in north-western Ontario. The treaty covers 55,000 square miles, an area slightly larger than New Brunswick and Nova Scotia combined. The Privy Council decided that the surrender of Aboriginal title benefitted Ontario because the province had the underlying title to the Saulteaux's lands due to section 109 of the Constitution Act, 1867, which provides that the original four provinces that joined together in Confederation retained most of their public lands.

That ruling has never been questioned by the courts, and I am not questioning it now. But in reaching this conclusion, the Privy Council also offered an opinion on Aboriginal title, describing it as "a personal and usufructuary right, dependent upon the good will of the sovereign." 3 As for the Crown's underlying, pre-treaty title, which their Lordships thought the Crown got as a result of the cession of French Canada to Britain by the 1763 Treaty of Paris, it was regarded as a substantial and paramount interest upon which the Aboriginal title was a mere burden.

Soon after Britain acquired New France, George III issued the Royal Proclamation of 1763 to protect Indigenous land rights in North America from unscrupulous settlers. Lord Watson, speaking for the Privy Council, said that the Saulteaux's possession of their lands, "such as it was," could only be attributed to the Proclamation. His description of Aboriginal title as a "personal and usufructuary right" was based entirely on his interpretation of the Proclamation. It was not based on the common law or Indigenous law.

\footnotetext{
${ }^{1}$ (1888), 14 App. Cas. 46 [St. Catherine's].

2 [1973] S.C.R. 313.

${ }^{3}$ St. Catherine's, above note 1 at 54 .
} 
This description governed the legal understanding of Aboriginal title from 1888 until 1973, when it was finally questioned by the Supreme Court in Calder. It was subsequently rejected by the Court in Delgamuukw v. British Columbia in 1997. ${ }^{4}$ Recently, in Tsilhqot'in Nation v. British Columbia ${ }^{5}$ the Court affirmed the holding in Delgamuukw that Aboriginal title amounts to the entire beneficial interest in the land, so the Crown's underlying title has no beneficial content whatsoever. My understanding is that the Crown's underlying title to unceded Aboriginal title land is equivalent to the Crown's right to escheat underlying a fee simple estate.

Given that the St. Catherine's decision's characterization of Aboriginal title as a personal and usufructuary right has been rejected by the Supreme Court, you might ask why is it still worthwhile to talk about this aspect of the case. Well, first of all, because I think legal history matters - it is important for us to understand why Lord Watson relied solely on the Royal Proclamation of 1763 to conclude that Aboriginal title is only a personal and usufructuary right.

But there is a second reason that may be even more important. Over the past few years, a debate has been developing over whether Aboriginal title amounted to a legal right enforceable against the Crown prior to the Calder decision in 1973. On one side are academics, myself included, who contend that Aboriginal title existed as a common law right from the time of British colonization of North America and that the Royal Proclamation merely confirmed this pre-existing right. ${ }^{6}$ On the other side are those who argue that Aboriginal title did not exist as a legal right enforceable against the Crown until Calder and more recent decisions altered the law and made it enforceable. ${ }^{7}$

This academic debate has surfaced in recent court cases in Canada, where the Crown has relied on expert testimony to argue that the Indigenous peoples of Canada had no legal rights to their lands in the nineteenth century. Their so-called "rights" were only moral or political, so it was entirely in the discretion of the government whether to acknowledge them and negotiate treaties for the surrender of Indigenous lands. ${ }^{8}$ So the nature of Aboriginal title in the nineteenth century is not merely a matter of legal history. The land rights of Indigenous peoples today can depend on the legal description of those rights in the past.

${ }^{4}$ [1997] 3 S.C.R. 1010 [Delgamuukw].

${ }^{5}$ [2014] 2 S.C.R. 257.

${ }^{6}$ E.g. see Brian Slattery, "Understanding Aboriginal Rights" (1987) 66 Can. Bar Rev. 727; Kent McNeil, Common Law Aboriginal Title (Oxford: Clarendon Press, 1989); Mark D. Walters, "Promise and Paradox: The Emergence of Indigenous Rights Law in Canada", in Benjamin Richardson, Shin Imai \& Kent McNeil, eds., Indigenous Peoples and the Law: Comparative and Critical Perspectives (Hart Publishing: Oxford, 2009), 21-50.

${ }^{7}$ E.g. see P.G. McHugh, Aboriginal Title: The Modern Jurisprudence of Tribal Land Rights (Oxford: Oxford University Press, 2011), esp. 111; Paul McHugh \& Lisa Ford, "Settler Sovereignty and the Shapeshifting Crown," in Lisa Ford \& Tim Rowse, eds., Between Indigenous and Settler Governance (Abingdon, UK: Routledge, 2013), 23 at 31-33; David V. Williams, "The Role of Legal History in Developing New Zealand Common Law Following Paki (No. 2)" [2016] N.Z. L. Rev. 755, esp. 785-86.

${ }^{8}$ E.g. see Ross River Dena Council v. Canada (A.G.), 2017 YKSC 58, [2018] 3 C.N.L.R. 47, esp. paras 61-62. For a case where the Crown argued (unsuccessfully) that it has unfettered discretion in interpreting and implementing a treaty provision, see Restoule v. Canada (Attorney General), 2018 ONSC 7701, 431 D.L.R. (4th) 32. 
Getting back to the St. Catherine's case, what caused Lord Watson to conclude that the Saulteaux's possession - and thus their land rights - could only be attributed to the Royal Proclamation of 1763? The answer, I think, is that there was no evidence to support any other source of these rights. In other words, what was lacking in the St. Catherine's case was not law to validate Indigenous land rights apart from the Proclamation, but facts to support the application of that law. What kind of facts?

First of all, facts demonstrating that the Saulteaux's occupation and use of the land amounted to possession. If they had possession, then the common law presumption of title from possession should have applied, as Justice Hall concluded in Calder and Chief Justice Lamer affirmed in Delgamuukw. ${ }^{9}$

Secondly, there was no evidence of Saulteaux law presented in the case. If there had been, Saulteaux land rights under their own laws should have continued after the Crown acquired sovereignty and should have been enforceable against the Crown. This is the way French land rights were treated after the British Crown acquired French Canada in $1763 .{ }^{10}$

The ideological, historical, and political context in the 1880s when St. Catherine's went to court probably had an impact on the way the case was decided. Let me mention a few relevant factors. First, racist theories based on the concept of social evolution were at their height in the 1880s. "Armchair anthropologists" who had little or no direct experience of Indigenous peoples speculated that human societies evolved from savage up through barbaric to civilized, in much the way Darwin said species evolve. Indigenous societies in North America were regarded as occupying the lower rungs of this evolutionary scale, whereas Europeans of course were at the top.

The trial judge in St. Catherine's, Chancellor Boyd, obviously shared these views. His judgment is riddled with racist language revealing his attitude that the Indian tribes of North America, and the Saulteaux in particular, were too primitive to have laws or any rights to their lands. What is remarkable is that no evidence was presented in the case to support these views. The Saulteaux were not parties and no Saulteaux were called as witnesses. The sole witness was Alexander Morris, the head negotiator of Treaty 3 for the Crown. The transcript of his testimony is only two pages long - all he did was confirm that the treaty had been negotiated and entered into in 1873. Other than that, all the evidence was documentary, dealing mainly with the historical relationships between the Crown and Indigenous peoples. There was virtually no evidence of Saulteaux society and land use and no evidence at all of their laws.

\footnotetext{
${ }^{9}$ Calder, above note 2 at 375; Delgamuukw, above note 4 at para. 149; R. v. Marshall. R. v. Bernard, [2005] 2 S.C.R. 220 at paras. $54,131,138$.

${ }^{10}$ See Drulard v. Welsh (1906), 11 O.L.R. 647 (Ont. D.C.), Boyd C., reversed on other grounds (1907), 14 O.L.R. 54 (Ont. C.A.).
} 
Without evidence, how did Chancellor Boyd arrive at his conclusions that the Saulteaux were primitive savages who were "more degraded than the usual Indian type"? ${ }^{11}$ The answer, I think, is that these were simply prejudiced assumptions based on racist attitudes that were all too prevalent in Anglo-Canadian society in the 1880s.

Regarding the historical context, in the 1880s some of the most oppressive measures were being taken against the Indigenous peoples of North America. For example, the allotment system was implemented in the United States to break up the reservations into individual plots that would become alienable, causing the Indian nations to lose two-thirds of their lands between 1887 to 1934 when allotment was ended. In Canada, Indian Act amendments banned the potlatch and sun dance and strengthened the band council system in order to terminate traditional Indigenous governments. This was also the decade when residential schools became official policy with the express purpose of destroying Indigenous cultures and assimilating Indigenous children.

It is also significant that the St. Catherine's trial was taking place at the same time the second Riel Resistance was happening at Batoche. In fact, two of Chancellor Boyd's sons were soldiers fighting against the Métis and the Cree who joined the resistance, and the Chancellor and all the lawyers involved made financial contributions to the cause of putting down the uprising.

Unfortunately, Boyd C's racist assumptions about Saulteaux society were part of the factual record available to the judges on appeal. The Privy Council, sitting in far-off London, had no other assessment of Saulteaux society upon which to base their decision. No wonder Lord Watson concluded that Saulteaux possession of land, "such as it was," could only be attributed to the Royal Proclamation. If evidence of Saulteaux land use and law had been available to their Lordships, the result might have been different.

This is evident from three Privy Council decisions handed down not long after St. Catherine's: Nireaha Tamaki v. Baker ${ }^{12}$ from New Zealand, and Re Southern Rhodesia ${ }^{13}$ and Amodu Tijani v. Secretary, Southern Nigeria ${ }^{14}$ from Africa. In the first two, their Lordships held that, if evidence of Indigenous land rights under local customary law were presented, the courts would enforce that law. In Amodu Tijani, the Privy Council did just that - it upheld the land rights of the Nigerians against the Crown because there was sufficient evidence of those rights in local African law. So one possible source of Indigenous land rights in the nineteenth and early twentieth centuries is Indigenous law.

A second potential source is possession of land and the common law rule that possession is a root of title. As already mentioned, that was one of Justice Hall's reasons for deciding in Calder that

\footnotetext{
${ }^{11}$ St. Catharine's Milling and Lumber Company v. The Queen (1885), 10 O.R. 196 (Ont. Ch.) at 211.

12 [1901] A.C. 561.

13 [1919] A.C. 211.

${ }^{14}$ [1921] 2 A.C. 399.
} 
the Nisga'a had Aboriginal title. He dissented on the issues of Crown immunity and extinguishment, but not on the source of Aboriginal title. Justice Judson also said that Aboriginal title in British Columbia does not depend on the Royal Proclamation of 1763, but arises instead from the fact that Indigenous peoples were occupying and using land as organized societies when the Europeans arrived. That made six out of seven Supreme Court judges who decided that Aboriginal title is a legal right.

In Delgamuukw in 1997, Chief Justice Lamer affirmed that there are two possible sources of Aboriginal title apart from the Royal Proclamation: Indigenous law and the common law rule that title is grounded in possession. The Indigenous law source was affirmed in Nireaha Tamaki, Re Southern Rhodesia, and Amodu Tijani. The common law source relies on a principle that goes back all the way to the assize of novel decision and other real property actions originating in the early common law. Application of this principle can also be found in numerous adverse possession cases from the nineteenth century and earlier. The principle that possession is a root of title is one of the earliest and most fundamental principles of common law real property. To not apply it to the Indigenous peoples' use and occupation of land would be unjustified and highly discriminatory.

I think this is what the Supreme Court realized in Calder, Delgamuukw, and more recently in Tsilhqot'in Nation. But what made this possible was the factual record: in Calder, Nisga'a possession was admitted by the Crown, and in Delgamuukw and Tsilhqot'in Nation Indigenous possession was established by extensive evidence from Indigenous witnesses and experts.

Summing up, my main point is that there was ample law at the time of the St. Catherine's case for the Privy Council to decide that, quite apart from the Royal Proclamation, Aboriginal title is a legal right enforceable against the whole world, including the Crown. But to apply that law, courts need an adequate factual basis to do so. That is what was lacking in St. Catherine's, which is why the Privy Council resorted to the Proclamation as the basis for Indigenous land rights.

According to Delgamuukw, evidence in Aboriginal title cases needs to establish that the Indigenous claimants were in exclusive occupation at the time of Crown assertion of sovereignty. The Court told us in Delgamuukw that physical occupation and Indigenous law are both relevant to meet this burden of proof. Once exclusive occupation has been established by these means, it gives rise to Aboriginal title, which is not a mere "personal and usufructary right dependent on the good will of the sovereign." It is a legal and constitutional right amounting to the entire beneficial interest in the land. ${ }^{15}$ On the basis of the extensive evidence of occupation and use in accordance with Tsilhqot' in law that was led at trial, ${ }^{16}$ this is the interest the Tsilhqot'in people have in their land as a result of the Supreme Court's decision in the Tsilhqot'in Nation case.

\footnotetext{
15 Aboriginal title enjoys constitutional protection as an Aboriginal right due to s.35 of the Constitution Act, 1982.

16 Tsilhqot'in Nation v. British Columbia, [2008] 1 C.N.L.R. 112 (B.C.S.C.).
} 